The Geneva Papers on Risk and Insurance, 20 (No. 75, April 1995) 230-245

\title{
The Cost Structure of Distribution Systems in the U.S. Property/Liability Insurance Market
}

\author{
by Arthur M.B. Hogan *, Peruvemba K. Satish ${ }^{* *}$ and Robert C. Witt ${ }^{* * *}$
}

\begin{abstract}
This paper examines the relative efficiencies of the two major distribution systems for property/casualty insurance : (1) independent agents and brokers (the independent intermediary), and (2) direct writers (the captive intermediary). The cost functions of the independent and captive systems of the property/casualty insurance industry are estimated using the generalized Cox-Box multiproduct cost function model. For firms operating at their mean output level, there are diseconomies of scale in both distribution systems. However, we do find evidence of economies of scale for the direct writers operating at the independent agency firm's output level. Nor do global economies of scope appear to exist for either distribution system. Pairwise cost complementarities for the pairing of commercial liability with either commercial property or personal liability are possible for firms using the independent agent system. This might arise from the range of contracts offered through independent agents and brokers. While for direct writers only the pairing of commercial liability and commercial property or personal liability with personal property have possible cost complementarities. This is consistent with the belief that direct writers have lower marketing costs for the standardized policies, such as those found in the personal lines. These empirical results help to resolve an inconsistency of prior studies of the efficiency of the two types of distribution systems.
\end{abstract}

\section{Introduction}

Property and liability insurers predominantly tend to distribute insurance through either (1) exclusive company agents (direct writing) or (2) through brokers and independent agents, who are basically treated as brokers by the legal system. An exclusive agent or a salaried sales person for a direct writer represents one insurance company, and cannot

* Office of Thrift Supervision, 1700 G Street, N.W., Washington, DC 20552.

* Department of Finance, Washington State University, Richland, WA 99352.

*** Department of Finance, University of Texas, Austin, TX 78712. 
represent other insurers without permission..$^{1}$ If an exclusive agent's relationship with the company ends, customer information belongs to the company, and not to the agent. ${ }^{2}$ However, the insurer cannot assign a different agent to do the renewal business unless the policyholder leaves the agent's territory or specifically requests an agent change. Exclusive agents and direct-writer salespersons usually do not participate in claims adjustment, and in almost all cases, insurers issue the policy and collect the premium. An exclusive agent, unlike a direct-writer's salesperson, pays for operating expenses, but like the salaried salesperson usually receives support from the company for market research, sales training, advertising and office equipment. Exclusive agents and salespersons receive compensation as a combination of salary and commission. Additionally, salespersons, as employees of the firm, receive fringe benefits, such as worker's compensation. Renewal commissions paid to exclusive agents are typically lower than commissions paid for new business, because less effort is required for renewals.

Brokers and independent agents may represent more than one insurance company. The average number of companies represented by an independent agent is 5.5, according to Cummins and Weisbart (1977). Independent agents and brokers pay their operating expenses and own the expirations. They are compensated by pure commissions. Usually, there is no reduction in commission rates for renewals, because of the agents' ownership of renewals. Some commissions may be contingent upon the underwriting performance to encourage and enhance risk selection by agents.

This study examine the relative efficiency of the two major types of property/casualty insurance distribution systems: (1) the direct writers with exclusive company agents or (2) the independent agent system. Efficiency is assessed by estimating the economies of scale and economies of scope for the two distribution systems. Two types of cost functions are fitted separately for each of the distribution systems. The hypotheses tested are: (1) independent agents are less efficient than exclusive agents or no significant difference in efficiency exists, (2) independent agents have a comparative advantage in writing commercial lines or no difference exists, and (3) independent agents have an advantage in smaller markets with greater geographical dispersion or they have a disadvantage. The methodology used in this study has an advantage over other methods of examining efficiency, such as X-efficiency measures or envelop analysis, in that our method allows the accounting data to be noisy.

The existence of economies of scale and scope for the insurance industry have been examined in the past by Joskow (1973), Cummins (1971), Cummins and Van Derhei (1979), Johnson, Flanigan, and Weisbart (1981), Harrington (1982), Cather, Gustavson and Trieschman (1985), Fields and Murphy (1989) and Grace and Timme (1992). More recently,

1 Permission is sometimes given if the exclusive agent is unable to place the business with the original insurer due to company underwriting standards or because the coverage is not available from the original insurer.

2 Policy expirations are the information regarding names, addresses, and ages of policyholders of the Company; the description and location of insured property; and expiration of renewal dates of the Company's policies acquired or coming into your possession during the effective period of this Agreement, or any prior agreement, are trade secrets wholly owned by the Company. All forms and other materials, whether furnished by the Company or purchased by you, upon which this information is recorded shall be the sole and exclusive property of the Company. (Webb et al 1981, p. 68.) 
Cummins and Weiss (1993) and Gardner and Grace (1993) have analyzed the efficiency of the insurance firms. Gardner and Grace (1993) examine the relative efficiency of the life insurers in their sample, whereas Cummins and Weiss (1993) focus on the efficiency of the property and liability firms. In both studies, the cost function of the insurance firms is estimated by modeling it as a translog cost function. Cummins and Weiss (1993) study the efficiency of the large, medium and small property and liability firms separately by estimating a stochastic cost frontier.

The international evidence on the returns to scale in the property-liability insurance industry has been mixed. The studies of EC countries have fund the existence of scale and scope economies in Belgium (Laboul and Lauwers, 1986), Sweden (Skogh, 1982), France (Outreville, 1987); (Rosa, 1984); Italy (Eisen, 1991) and the United Kingdom (Praetz, 1985). Only one study for France (Dubois, 1988) has reported no economies.

This study differs from the previous papers on the estimation of cost function for insurance firms in several ways. Gardner and Grace (1993) and Grace and Timme (1992) focus their attention on life insurance firms, whereas we focus our attention on property and liability insurance (P\&L) firms. Cummins and Weiss (1993), in their study of efficiency of P\&L insurance firms do not distinguish between the type of insurance distribution system utilized. However, it has been argued that minimization of agency cost can lead to property and casualty insurance firms preferring one form of the distribution system over the other. Since agency costs can affect the cost structure of insurance firms fundamentally, we separate the P\&L insurers on the basis of their insurance distribution systems and examine the efficiency of insurers in each group.

The rest of the paper is organized as follows. In section 2 , the arguments made in the literature on the efficiency of the two distribution systems are reviewed. The data and the estimated cost functions are described in section 3 . The principal results are presented in the section 4. Conclusions are presented in section 5 .

\section{Independent agent versus direct writers}

Joskow (1973), Etgar (1977), and Cummins and Van Derhei (1979) argue that higher average product prices for independent-agency insurers provide evidence of inefficient operations. However, inefficient systems should not survive (Alchian, 1950) in a competitive market. In Europe, Finsinger and Schmidt (1994) have attributed the dominance of particular marketing systems to regulatory barriers. However, competition in the U.S. insurance industry should be forested by the low barriers to entry and the large number of insurers (Witt and Aird, 1992).

Marvel (1982) argues that the direct writer system protects an insurer's property rights to its advertising and promotion investments by preventing agents from diverting potential policyholders to other insurers who incur fewer advertising expenditures, but pay larger commissions. The insurer vertically integrates the distribution system to control the possibility of the agent exploiting the firm's promotional efforts (Klein, Crawford and Alchian, 1978). The implication that direct writers spend more on advertising is supported by the higher ratio of advertising expenses to net premiums written for the direct writers, according to Marvel (1982). He further suggests that the importance of company-level versus agent-level promotion varies between personal and commercial lines of insurance. Personal lines constitute a larger homogenous market, where large-scale advertising and centrally conducted market research are more likely to be effective due to the homogenous market. 
Grossman and Hart (1986) note that insurers may also have expropriation incentives with respect to agents. Agents expend effort to attract and retain customers. Since monitoring is costly, agent compensation is based on actual policy renewals. Insurers could expropriate the agent's investment and save renewal commissions by renewing business directly with the customer without some constraints. Grossman and Hart (1986) argue that independent agent's ownership of policy expirations controls or moderates this incentive conflict. Reagan and Tennyson (1993) extend this analysis. They argue that even though independent agents are not involved in the underwriting decision, the ownership of renewals by independent agents provides a strong incentive for independent agents to correctly match risks and coverage.

The Marvel (1982) and Grossman and Hart (1986) analyses imply that when an insurance company specializes in insurance lines where insurer promotion is more effective than in other lines, agents will be able to free-ride on insurer promotion. The direct writing system can be used to control this free rider problem. Conversely, when the insurer specializes in lines where agent promotion is more effective, opportunities for insurer expropriation of agent investments are greater, and the independent-agent system with agent-owned expirations can reduce this conflict.

A confounding problem arises from the necessity of firms to be able to provide sufficient income to agents. Sass and Gisser (1989) argue that rational agents are willing to accept an exclusive-dealing arrangement only if their income exceeds the amount they earn elsewhere. They note this constraint implies that, to offer sufficient business for the agent, larger firms are more likely to use direct writers than smaller firms are. Additionally, Sass and Gisser (1989) argue that direct writers have a comparative advantage in more geographically concentrated markets. Since they represent only one insurer, exclusive agents generally offer a narrower range of policies and are more competitive in larger markets where the gains from specialization may be greater. However, Brickley and Dark (1987) suggest that greater geographic dispersion increases monitoring costs, since the insurer-agent relationship is an employment relationship for direct writers.

Kim, Mayers and Smith's (1991) analysis of distribution-system choice suggests a different interpretation of the cost structure than that suggested by Joskow (1973) or Cummins and Van Derhei (1979), and offers no support for the Grossman and Hart (1986) and Marvel (1982) hypotheses concerning advertising policy. Kim, Mayers and Smith (1991) argue that evidence of higher policy premiums for independent agency insurers reflects additional service provision to policyholders, not inefficiency.

For example, Kim, Mayers and Smith (1991) suggest that independent agents can influence claims-administration services by interceding on the policyholder's behalf with the company's claims adjuster. They argue that independent agents have more bargaining power for claim settlements because of their expertise and their ability to switch their business. These advantages may be more important for insurance against risks where the coverage involves a more lengthy, complex, and costly claims-settlement process. Therefore, insurance firms using independent agents should provide more high-service, high-price coverage, while firms employing exclusive agents should provide more low-service, low-price coverage, other things being equal. Hence, it is possible that agent provided services are sufficiently important in some personal lines to allow independent agents to efficiently deliver these services. In the Kim, Mayers and Smith (1991) analysis, the comparative advantage of 
independent agents arises from economies in information and claims-administration costs. Zweifel and Ghermi (1990) have empirical evidence from the Swiss market that indicates that independent agents have greater concern about cost. Independent agents reduce information costs by reducing policyholder search costs, since they can provide information about companies they represent. In essence, they can be perceived as information intermediaries who reduce consumer search costs.

\section{Data and methodology}

The gross premiums and expenses incurred under each distribution system were obtained for all groups of companies from the 1981-1989 Premium-Loss-Expense tapes for Property/casualty insurers of the A. M. Best Company. Data on the rental rates and wage rates for 1981-1989 were obtained from the General Services Administration Summary of U.S. Real Property Rental Around the World and the U.S. Department of Commerce Hours and Wages, respectively. For each types of distribution system, the gross premiums written in indifferent lines of insurance have been classified into main groups: commercial liability, commercial property, personal liability and personal property. Table 1 presents the different lines belonging to each of these four groups.

Table 1: Lines of insurance in each of the four groups: commercial liability, commercial property, personal liability and personal proper

\begin{tabular}{|c|c|c|c|}
\hline $\begin{array}{c}\text { Commercial } \\
\text { liability }\end{array}$ & $\begin{array}{c}\text { Commercial } \\
\text { property }\end{array}$ & $\begin{array}{c}\text { Personal } \\
\text { liability }\end{array}$ & $\begin{array}{c}\text { Personal } \\
\text { property }\end{array}$ \\
\hline $\begin{array}{c}\text { Commercial } \\
\text { liability } \\
\text { Commercial } \\
\text { auto liability } \\
\text { Airline }\end{array}$ & Inland marine & $\begin{array}{c}\text { Personal auto } \\
\text { liability }\end{array}$ & Homeowners \\
Surety & $\begin{array}{c}\text { Commercial } \\
\text { auto } \\
\text { Boiler }\end{array}$ & & $\begin{array}{c}\text { Personal auto } \\
\text { property }\end{array}$ \\
Fidelity & & & \\
Other liability & & & \\
\hline
\end{tabular}

\section{Output measure}

An issue in the study of returns to scale and scope in the insurance industry is how to measure the service component of output. Revenues may more accurately measure this type of output than assets. ${ }^{3}$ The majority of scholars have settled upon premiums as the most appropriate measure. However, Geehan (1977) has argued theoretically that premiums exaggerate scale economies, while Doherty (1981) has argued theoretically that

${ }^{3}$ The use of revenue as a mesure of output, however, may contain a bias if market prices for insurance firms' services are systematically related to measures of quantities of insurance service output. 
premium measures suppress scale economies. Doherty (1981) and Skogh (1982) have suggested using claims-based measures. However, the use of claims as a measure captures only one component of output of an insurer, and this output measure is included in premiumbased measures, because premiums include estimates of losses or claims. ${ }^{4}$

Additionally, premium estimates of output capture claims adjustment, legal activities, loss control, risk management, data processing, education, financial intermediation, and political service components of the insurance product, according to Schlesinger and Venesian (1990). The addition of loss-adjustment expenses to losses might improve the loss-cost measure; however, it would still not capture the important aspects of insurer activities. Denny (1980) has demonstrated econometrically that claims-based measures of output are biased in that insurers with the lowest loss ratios will appear to be comparatively less efficient if they emphasized loss-prevention services. These loss-prevention costs would be embedded in the expense component of the premium rate. For these reason and to facilitate comparison with prior work, recent studies by Fields and Murphy (1989), Eisen (1991), Kaye (1991), Fecher, Perelman, and Pesticau (1991), Sigma (4/91 pp. 1-20) and this paper use premiums as the measure of insurer output.

To account for changes in product prices all variables have been standardized by dividing by the mean for that year. Additionally, although firms may be in the process of adjusting prices as well as output, there is no reason to believe a priori that there is a systematic relationship of price with size or product mix of firms. ${ }^{5}$ Since in either competitive markets or regulated markets, prices should be clustered or reasonably uniform among firms. ${ }^{6}$ As in most studies of financial services, equal risk-adjusted cost of capital for all firms is assumed, and therefore, the cost of capital is excluded from the model. ${ }^{7}$

\section{Functional form}

The multiproduct generalized Box-Cox cost function estimated in this study can be expressed as follows:

4 It should be noted that a claims-based measure relies on the estimation of incurred, but not reported losses, and therefore, does not remove the possibility of estimation bias.

${ }_{5}^{5}$ Pairwise cost complementarities exist between outputs $i$ and $j$ when

$$
\frac{\partial^{2} C}{\partial Q_{i} \partial Q_{1}}<0 \exists i \neq j
$$

where $C$ is the cost function and $Q_{i}$ and $Q_{j}$ are elements of the output vector.

${ }^{6}$ In markets characterized by product differentiation, there may be a systematic relationship between price and firm size where larger firms are seen to offer quality products. In such a case, higher prices will be associated with greater output and overall size. This suggests that revenues will tend to be proportionately larger than costs indicating scale economies for larger firms. However, this will not be the case if small firms find a niche by differentiating their product.

${ }^{7}$ Fecher, Perelman and Pesticau (1991) suggest that reinsurance might be used as a measure of the cost of equity. Reinsurance involves the sale of premium for future coverage. Reinsurance is just the securitization of part of an insurer's underwritings. It is analagous to the syndication of a collateralized mortgage obligation (CMO). Excess loss reinsurance, in which the reinsurer covers losses above a fixed amount are covered, is equivalent to the firm keeping the riskiest tranches of the CMO and selling the least risky. Treaty reinsurance, in which the reinsure shares in the losses, is equivalent to selling a fraction of all the tranches of a CMO. In neither case is the buyer providing capital to the firm as a whole; therefore, neither the required rate of return on the $\mathrm{CMO}$ or on reinsurance has any relationship to any component of the firm's cost of capital. 


$$
\begin{gathered}
C(\lambda)=\alpha_{0}+\sum_{i=1}^{4} \alpha_{i} Q_{i}(\lambda)+\frac{1}{2} \sum_{i=1}^{4} \sum_{j=1}^{4} \beta_{i j} Q_{i}(\lambda) Q_{j}(\lambda) \\
+\chi S(\lambda)+\sum_{i=1}^{2} \delta_{i} P_{i}+\frac{1}{2} \sum_{i=1}^{2} \sum_{j=1}^{2} \varepsilon_{i j} P_{i}(\lambda) P_{j}(\lambda) \\
+\sum_{i=1}^{4} \phi_{i} Q_{i}(\lambda) S(\lambda)+\sum_{j=1}^{2} \eta_{i} P_{i}(\lambda) S(\lambda)+\frac{1}{2} \sum_{i=1}^{4} \sum_{j=1}^{2} \gamma_{i j} Q_{i}(\lambda) P_{j}(\lambda)
\end{gathered}
$$

where $(\lambda)$ after the variables indicates the Box-Cox transformation:

$$
G(\lambda)=\frac{G^{\lambda}-1}{\lambda}
$$

with the symmetry restriction

$$
\beta_{i j}=\beta_{j i}, \varepsilon_{i j}=\varepsilon_{j i}, \gamma_{i j}=\gamma_{j i} \forall i, j
$$

and the following homogeneity restrictions

$$
\sum_{i=1}^{2} \delta_{i}=1 ; \sum_{i=1}^{2} \varepsilon_{i j}=0, \sum_{i=1}^{2} \gamma_{i j}=0 \forall j
$$

where

$C=$ Total expenses or costs

$Q_{i}=$ Gross premium for personal property, personal liability, commercial property and commercial liability

$S=$ Geographical measure - the number of states the firm underwrites in

$P_{1}=$ Labor cost on a yearly basis

$P_{2}=$ Cost of rental space per square foot

This function estimates scale economies and tests product mix effects on cost. The variable for the number of states in which the firm has underwriting activities, $S$, is roughly equivalent to a similar variable used in most banking studies. It measures the costs incurred in dealing with numerous additional regulators. Symmetry is imposed in order that the estimates obtained from the cost function will be the same as those obtained from a dual production function.

Additional information is incorporated to augment the single equation cost function. This information is derived from the cost-share equations for the cost function of the form:

$$
Y_{j}=\frac{\partial C(\lambda)}{\partial P_{j}(\lambda)}=\delta_{j}+\sum_{i=1}^{2} \varepsilon_{i j} P_{i}(\lambda)+\sum_{i=1}^{4} \gamma_{i j} Q_{j}(\lambda)+\sum_{i=1}^{2} \eta_{i} S(\lambda)
$$


One cost share equation is arbitrarily dropped from the system to remove the possibility of singularity. To remove the effect of the measurement unit, the variables are standardized by dividing by the mean (Spitzer, 1984). A non-linear version of the seemingly unrelated regression technique is used to estimate the parameters of this system of equations. The non-linear seemingly unrelated regression was done using the quasi-Newton gradient method.

The Box-Cox transformed total expense is the dependent variable. The estimation of scale economies at the mean can be measured from the sum of the first order terms for output since the variables have been scaled by their means. The significance can be examined by testing the hypothesis that the point estimate of the ray scale cost economies (RSCE) is unity. At the mean the estimate is:

$$
R S C E_{i}=\sum_{i=1}^{4} \frac{\partial C(\lambda)}{\partial Q_{i}(\lambda)}=\sum_{i=1}^{4} \alpha_{i}=1
$$

Firms may be able to reduce marginal costs by changing size and product mix. This effect is investigated by examining interproduct cost complementarities that measure the change in marginal cost of one product as a result of a change in another, a jointly produced product. Interproduct cost complementarities are defined as:

$$
\frac{\partial^{2} C}{\partial Q_{i} \partial Q_{j}}<0 \exists i \neq j
$$

and are computed as follows:

$$
\frac{\partial^{2} C}{\partial Q_{i} \partial Q_{j}}=\frac{C}{Q_{i} Q_{j}} \frac{\partial^{2} C(\lambda)}{\partial Q_{i}(\lambda) \partial Q_{j}(\lambda)}+\frac{\partial C(\lambda)}{\partial Q_{i}(\lambda)} \frac{\partial C(\lambda)}{\partial Q_{j}(\lambda)}
$$

The sign depends on the sign of the first term. This term is the estimated coefficient of the output interaction term in the cost function. The other terms are restricted to be positive on theoretical grounds. Thus, a negative value for the first term is a necessary, but not sufficient, condition for interproduct cost complementarities to exist between products $i$ and $j$. Thus, if this term is positive, interproduct cost complementarities cannot exist and there may be significant interproduct cost non-complementarities. An approximation of scope economies at the mean output is computed following the procedure of Denny and Pinto (1978):

$$
\frac{\partial^{2} C}{\partial Q_{i} \partial Q_{j}}=\alpha_{i} \alpha_{j}+\beta_{i j}
$$

where $\alpha_{i}, \alpha_{j}$ and $\beta_{i j}$ are coefficients from the cost function.

\section{Empirical results}

For perspective, Table 2 presents the mean total premiums collected by independent intermediaries for years 1981-1989. In each year, an independent intermediary has generated a greater share of their business by writing commercial liability and commercial property 
lines of insurance. Also, on the average an independent intermediary writes more liability insurance than property insurance. The mean total premiums collected by direct writers (captive or exclusive agent distributors) is shown in Table 3. The direct writers received a greater proportion of their premium income by writing personal liability and personal property lines of insurance. The figures in Table 2 support the arguments that insurers using independent agents and brokers tend to write relatively more liability insurance and commercial lines of insurance.

Table 2: Premiums collected by independent agents 1981-1989

\begin{tabular}{|c|c|c|c|c|c|c|}
\hline \multirow{2}{*}{ Year } & \multirow{2}{*}{$\mathrm{N}$} & \multirow{2}{*}{\begin{tabular}{c} 
Mean total \\
premium \\
\cline { 5 - 7 }
\end{tabular}} & & \multicolumn{3}{|c|}{ Market share by insurance lines } \\
\hline 1981 & 282 & 138.057 & $33.61 \%$ & $23.86 \%$ & $19.61 \%$ & $22.75 \%$ \\
\hline 1982 & 605 & 110.269 & 33.51 & 24.04 & 19.35 & 22.86 \\
\hline 1983 & 612 & 113.648 & 32.92 & 23.21 & 19.82 & 23.84 \\
\hline 1984 & 592 & 129.602 & 33.39 & 23.09 & 19.68 & 23.52 \\
\hline 1985 & 522 & 185.157 & 35.57 & 24.05 & 19.19 & 20.82 \\
\hline 1986 & 627 & 188.895 & 37.46 & 23.90 & 19.07 & 19.08 \\
\hline 1987 & 628 & 199.296 & 38.26 & 22.80 & 19.53 & 19.07 \\
\hline 1988 & 648 & 197.705 & 38.22 & 22.02 & 20.20 & 19.12 \\
\hline 1989 & 829 & 160.111 & 39.61 & 21.21 & 20.32 & 18.63 \\
\hline \multicolumn{3}{|c|}{ Mean } & $35.84 \%$ & $23.13 \%$ & $19.64 \%$ & $21.08 \%$ \\
\hline
\end{tabular}

Table 3: Premiums collected by exclusive agency insurers 1981-1989

\begin{tabular}{|c|c|c|c|c|c|c|}
\hline \multirow{3}{*}{ Year } & \multirow{3}{*}{$\mathbf{N}$} & \multirow{3}{*}{$\begin{array}{c}\text { Mean total } \\
\text { premium } \\
\text { \$million }\end{array}$} & \multicolumn{4}{|c|}{ Market share by insurance lines } \\
\hline & & & \multicolumn{2}{|c|}{ Commercial } & \multicolumn{2}{|c|}{ Personal } \\
\hline & & & Liability & Property & Liability & Property \\
\hline 1981 & 108 & 257.204 & $14.40 \%$ & $6.89 \%$ & $36.21 \%$ & $42.42 \%$ \\
\hline 1982 & 233 & 174.484 & 17.37 & 8.54 & 34.75 & 39.05 \\
\hline 1983 & 233 & 187.738 & 16.48 & 7.89 & $35 . \overline{41}$ & 39.86 \\
\hline 1984 & 230 & 205.769 & 15.95 & 8.56 & 35.21 & 39.92 \\
\hline 1985 & 192 & 297.418 & 18.00 & 10.21 & 33.91 & 37.54 \\
\hline 1986 & 210 & 326.248 & 19.59 & 9.17 & 34.59 & 36.09 \\
\hline 1987 & 210 & 363.068 & 18.89 & 9.03 & 35.05 & 35.98 \\
\hline 1988 & 214 & 382.642 & 18.64 & 8.85 & 35.79 & 35.74 \\
\hline 1989 & 280 & 311.255 & 16.83 & 8.72 & 37.30 & 35.80 \\
\hline \multicolumn{3}{|c|}{ Mean } & $17.35 \%$ & $8.65 \%$ & $35.36 \%$ & $38.84 \%$ \\
\hline
\end{tabular}


Table 4 reports the industry-wide market share of the premiums collected by independent agents and direct writers. Comparison of Table 2 and Table 3 reveals that the mean size of an direct writers, as measured by the premiums written, is larger than that of a firm using independent agents. But on the average, during 1981 through $1989,61 \%$ of the total insurance premiums were written by the independent agents. Approximately $36 \%$ of the premiums in commercial lines were written by independent agents compared to $10 \%$ of the total premiums written by direct writers in commercial lines. Nation-wide between 1981 and 1989 around $28 \%$ of the premiums in personal lines were collected by direct writers. Independent agents wrote approximately $25 \%$ of the insurance in personal lines during the same period.

Table 4: Industry-wide market share of total premiums collected by distribution type and insurance lines

\begin{tabular}{|c|c|c|c|c|c|c|c|c|}
\hline \multirow{3}{*}{ Year } & \multicolumn{4}{|c|}{ Independent agents } & \multicolumn{4}{c|}{ Exclusive agents } \\
\cline { 2 - 9 } & \multicolumn{2}{|c|}{$\begin{array}{c}\text { Commercial } \\
\text { Liability }\end{array}$} & \multicolumn{2}{c|}{ Personal } & \multicolumn{2}{c|}{ Commercial } & \multicolumn{2}{c|}{ Personal } \\
Liability & Property & Liability & Property & Liability & Property \\
\hline 1981 & $19.61 \%$ & $13.92 \%$ & $11.45 \%$ & $13.28 \%$ & $6.00 \%$ & $2.87 \%$ & $15.08 \%$ & $17.66 \%$ \\
\hline 1982 & 20.82 & 14.94 & 12.02 & 14.21 & 6.58 & 3.23 & 13.16 & 14.79 \\
\hline 1983 & 20.21 & 14.25 & 12.17 & 14.64 & 6.36 & 3.05 & 13.67 & 15.39 \\
\hline 1984 & 20.65 & 14.28 & 12.17 & 14.55 & 6.09 & 3.26 & 13.43 & 15.23 \\
\hline 1985 & 22.36 & 15.12 & 12.06 & 13.09 & 6.69 & 3.79 & 12.59 & 13.94 \\
\hline 1986 & 23.73 & 15.14 & 12.08 & 12.09 & 7.18 & 3.36 & 12.68 & 13.23 \\
\hline 1987 & 23.77 & 14.17 & 12.14 & 11.85 & 7.15 & 3.42 & 13.27 & 13.62 \\
\hline 1988 & 23.32 & 13.43 & 12.32 & 11.67 & 7.27 & 3.45 & 13.96 & 13.94 \\
\hline 1989 & 23.91 & 12.80 & 12.27 & 11.24 & 6.67 & 3.46 & 14.78 & 14.19 \\
\hline Mean & $22.04 \%$ & $14.23 \%$ & $12.08 \%$ & $12.96 \%$ & $6.66 \%$ & $3.32 \%$ & $13.62 \%$ & $14.67 \%$ \\
\hline
\end{tabular}

The results of the estimation of the Generalized Box-Cox model for insurers using independent and exclusive agents are presented in Table 5. The explanatory power of the cost function for firms using independents is indicated by an adjusted multiple $R^{2}$ of $0.48(0.47)$, and is significant as indicated by a F ratio of $33(19)$. The cost share equations have $R^{2}$ of $0.44(0.43)$ for salaries, and $0.45(0.47)$ for rent, with F ratios of $33(33)$ and $19(18)$, respectively. The explanatory power of the cost function for direct writers is indicated by an adjusted multiple $R^{2}$ of $0.48(0.48)$, and is significant as indicated by a $F$ ratio of $33(32)$. The cost share equations have $R^{2}$ of $0.47(0.44)$ for salaries, and $0.41(0.40)$ for rent, with $\mathrm{F}$ ratios of of 41 (35) and 44 (32), respectively. The first order terms are positive, which is consistent with the standard economic interpretation that total cost rises as output increases.

Table 6 presents the estimates of the economies of scale for independent agency and direct writer distribution systems. For the firms using independent agents, the measure of scale economies at their mean output level was 2.86 . Likelihood ratio test reveals that this is significantly different from unity at the $5 \%$ level. This indicates significant diseconomies of scale for insurers using independent agency distribution system. The economies of scale 
Table 5: Multiproduct cost function parameter estimates for insurers

\begin{tabular}{|c|c|c|}
\hline Variable & Independent agents & Exclusive agents \\
\hline Lambda & $0.663981^{* * *}$ & $0.629853^{* * *}$ \\
\hline Int ¿rcept & 0.063067 & 0.091327 \\
\hline Cominercial property & $0.679373^{* * *}$ & $0.848191^{* * *}$ \\
\hline Commercial liability & $0.725618^{* * *}$ & $0.741496 * * *$ \\
\hline Personal property & $0853739^{* * *}$ & $0.750065^{* * *}$ \\
\hline Personal liability & 0.600279 & 1.451495 \\
\hline Personal expense & 0.011856 & $0.050531^{* * *}$ \\
\hline Facility expense & $0.988144^{* * *}$ & $0.949469^{* * *}$ \\
\hline Geographic distribution & -0.173334 & 0.480918 \\
\hline Commercial liability $\mathrm{x}$ commercial liability & $-0.005824^{* * *}$ & $-0.000730^{*}$ \\
\hline Commercial liability $\mathrm{x}$ commercial property & $-0.005715^{* * *}$ & -0.000362 \\
\hline Commercial liability $\mathrm{x}$ personal liability & $-0.003615^{* * *}$ & 0.000541 \\
\hline Commercial liability x personal property & $-0.294626^{* * *}$ & $0.176108^{* * *}$ \\
\hline Commercial property $\mathrm{x}$ commercial property & $-0.003424 * * *$ & $0.003509^{* * *}$ \\
\hline Commercial property $\mathrm{x}$ personal liability & -0.001413 & $0.027206^{* * *}$ \\
\hline Commercial property $\mathrm{x}$ personal property & $0.242811^{* * *}$ & $0.566277^{* * *}$ \\
\hline Personal liability $\mathrm{x}$ personal liability & $0.003979^{* * *}$ & $-0.019438 * * *$ \\
\hline Personal liability $\mathrm{x}$ personal property & 0.430398 & -0.182485 \\
\hline Personal property $\mathrm{x}$ personal property & -1.176412 & -0.887475 \\
\hline Facility expense $\mathrm{x}$ commercial liability & $-0.021207^{* * *}$ & $-0.014298^{* * *}$ \\
\hline Facility expense $\mathrm{x}$ commercial property & $-0.018418^{* * *}$ & $-0.038687^{* * *}$ \\
\hline Facility expense $\mathrm{x}$ personal liability & -0.007750 & $-0.056330^{* * *}$ \\
\hline Facility expense $\mathrm{x}$ personal property & 0.007507 & $-0.029503 * * *$ \\
\hline Facility expense $\mathrm{x}$ geographic distribution & 0.401819 & 0.396428 \\
\hline Facility expense $\mathrm{x}$ personnal expense & $-0.060853^{* * *}$ & $-0.095790^{* * *}$ \\
\hline Facility expense $\mathrm{x}$ facility expense & $0.054419^{* * *}$ & $0.079366^{* * *}$ \\
\hline Personal expense $\mathrm{x}$ commercial liability & $0.021207 * * *$ & $0.014298^{* * *}$ \\
\hline Personal expense $\mathrm{x}$ commercial property & $0.018418^{* * *}$ & $0.038687^{* * *}$ \\
\hline Personal expense $\mathrm{x}$ personal liability & 0.007750 & $0.056330^{* * *}$ \\
\hline Personal expense $\mathrm{x}$ personal property & -0.007284 & $0.029503^{* * *}$ \\
\hline Personal expense $\mathrm{x}$ geographical distribution & $-10.033423^{* * *}$ & $-0.043074^{* * *}$ \\
\hline Personal expense $\mathrm{x}$ personal expense & $0.006434^{* * *}$ & $0.016424 * * *$ \\
\hline Geographic distribution $\mathrm{x}$ commercial liability & $0.008508^{*}$ & $0.012371^{* * *}$ \\
\hline Geographic distribution $\mathrm{x}$ commercial property & $-0.010930^{* *}$ & $-0.034694 * * *$ \\
\hline Geographical distribution $\mathrm{x}$ personal liability & $0.011911^{* * *}$ & $0.019859 * * *$ \\
\hline Geographical distribution $\mathrm{x}$ personal property & $-1.044261^{* * *}$ & $-1.090672^{* * *}$ \\
\hline Geographical distribution $\mathrm{x}$ geographical distribution & $-0.013701 * * *$ & -0.009032 \\
\hline
\end{tabular}


Table 6: Estimates of Economies of Scale

\begin{tabular}{|c|c|}
\hline $\begin{array}{c}\text { Distribution } \\
\text { system }\end{array}$ & $\begin{array}{c}\text { Estimate } \\
\text { of scale }\end{array}$ \\
\hline $\begin{array}{c}\text { Independent agents at their } \\
\text { mean output level }\end{array}$ & $2.86^{* *}$ \\
\hline $\begin{array}{c}\text { Independent agents at the } \\
\text { mean output level of the } \\
\text { exclusive agents }\end{array}$ & $2.84^{* *}$ \\
\hline $\begin{array}{c}\text { Exclusive agents at their } \\
\text { mean output level }\end{array}$ & $3.79^{* *}$ \\
\hline $\begin{array}{c}\text { Exclusive agents at the mean } \\
\text { output level of the } \\
\text { independent agency }\end{array}$ & $0.42^{* *}$ \\
\hline
\end{tabular}

** Significant at $5 \%$ level

of the independent agency distribution system is also measured by scaling it by the mean output level of the direct writers. Such a technique gives an estimate of the economies of scale resulting from forcing one distribution system (independent agency) to operate at the output level of an alternative distribution system (exclusive agency). It is found that the economies of scale of the independent distribution system at the mean output level of the exclusive agency distribution system is 2.84 . The is also significantly different from unity at $5 \%$ level and exhibits diseconomies of scale. However, such a result is not surprising. The mean output of the exclusive agency is higher than the mean output of the independent agency. The independent agency distribution system exhibits diseconomies of scale at its mean output level. Therefore, constraining the independent agency distribution system to operate at an even higher mean output level of the exclusive agency causes the diseconomies of scale to persist.

For the direct writers, the measure of scale economies at the mean output level was 3.79. This differs from unity at the $5 \%$ level, as determined by the likelihood ratio test, indicating that there are significant diseconomies of scale for insurers using exclusive agents. When forced to operate at the mean output level of the independent agency distribution system, the diseconomies disappeared. The estimate of economies of scale at the mean output level of the independent agents was 0.42 , but is not significantly different from unity.

There are also no global economies of scope, since some of the cross-line terms are positive. For direct writers, the cross terms are negative for the pair of commercial property and commercial liability, and personal property and personal liability. The cross term for commercial property with either personal line, and the cross term for commercial liability with personal property are positive. Indicating cost discomplementarities.

Pairwise cost complementarities are consistent with negative cross terms. For firms using independent agents, all the cross terms for commercial liability and the pair of commercial property with personal liability are negative. Like the direct writers, the cross terms 
for commercial and personal property is significantly positive; however, unlike the direct writers, the cross term for personal property with personal liability is significantly positive, which indicates an advantage for the direct writers in the personal lines.

\section{Conclusion}

Both distribution systems for property/liability insurance exhibit diseconomies of scale indicating that neither system is operating efficiently at its mean output level. However, insurers using independent distributors appear to be operating further from their optimal scale because they have a relatively smaller statistic. The results are consistent with the findings of Joskow (1973), Etgar (1977) and Cummins and Van Derhei (1979). But, the negative coefficients for geographical diversity do not support Brickley and Dark (1987), or Sass and Gisser (1989) argument that geographical diversity would be increase the costs for firms using independent agents.

For insurers, global economies of scope can be rejected. These firms exhibit pairwise complementarity for the pairing of commercial and personal liability. The results are consistent with firms using independent agents having cost complementarities for several of the output parings. This result is consistent with their being overlap in the services that might be required by the sole proprietor of the members of a small partnership. On the other hand, direct writers have a pairwise complementarity for personal property and personal liability, and commercial property and commercial liability, which is consistent with these two lines using the same marketing channel. The result for the personal lines is not duplicated by firms using independent agents. The finding of differential economies are consistent with the hypotheses of Marvel (1982), Grossman and Hart (1986), Sass and Gisser (1989), and Kim, Mayers and Smith (1991).

Thus, competitive advantages appear to exist for independent agency insurers who write a range of business including commercial coverage with some personal coverage. ${ }^{8}$ The underwriting of the personal lines will be limited by the diseconomies found from writing both personal property and personal liability. On the other hand, insurers using direct writers gain a competitive advantage by using the cost advantage of their marketing system to focus on either the personal lines or the commercial lines. This is borne out by the types of underwriting done on average through the two marketing channels. Table 2 shows that the independent agents do the bulk of their business in the commercial lines, while as shown in Table 3, the personal line compose the greater portion of the direct writers' business. Table 4 shows the advantage as translated into market share, since the independent agents have a greater portion of the commercial premiums, and the direct writers have a greater portion of the personal premiums. Each marketing channel's competitive advantage (Porter, 1985) appears to result from coordinating lower costs and cost effective differentiation of product mixes. That is, insurers may gain a competitive advantage by coordinating their mix of coverage with their marketing system in order to perform their activities at a lower average cost. Economies of scale and scope, capacity utilization, quality, reliability, reputation and other factors may be combined in unique ways to generate competitive cost advantages.

\footnotetext{
${ }^{8}$ Umbrella riders for personal liability can be attached to automobile liability policies.
} 


\section{REFERENCES}

ALCHIAN, Armen, "Uncertainty, Evolution and Economic Theory", Journal of Political Economy No. 8, June 1950, pp. $211-21$.

BAUMOL, W., PANZAR, J. and WILLIG, R., Contestable Markets and the Theory of Industry Structure, Harcourt Brace Javanovich, San Diego, CA, 1982.

BERNDT, E. R. and KHALED, M. S., "Parametric Productivity Measurement and Choice Among Flexible Functional Forms", Journal and Political Economy No. 87, December 1987, pp. 1220-1245.

BRICKLEY, James and DARK, Frederic, "The Choice Organizational Form: The Case of Franchising", Journal of Financial Economics No. 14, 1987, pp. 401-20.

CATHER, David, GUSTAVSON, Sandra and TRIESCHMANN, James, "Profitability Analysis of Property-Liability Insurers Using Alternative Distribution Systems", Journal of Risk and Insurance No. 52, June 1985, pp. 321-32.

CHO, Dongese, "Some evidence of Scale Economies in Workers' Compensation Insurance", Journal of Risk and Insurance No. 55, June 1988, pp. 324-330.

CUMMINS, David and WEISBART, Steven, The Impact of Consumer Services on Independent Insurance Agency Performance, IMA Education and Research Foundation, 1977.

CUMMINS, J. David, "Economies of Scale of Independent Insurance Agencies", Journal of Risk and Insurance, No. 44, December 1977, pp. 539-553.

CUMMINS, J. David and VANDERHEI, Jack, "A Note on the Relative Efficiency of Property-Liability Insurance Distribution Systems", Bell Journal of Economics and Management Science No. 10, Spring 1979, pp. 709-719.

CUMMINS, J. David and WEISS, M.A., "Cost Efficiency in the Property-Liability Insurance Industry", Journal of Banking and Finance No. 17 September 1993, pp. 463-481.

DALY, M., RAO, P. S. and GEEHAN, R., "Productivity, Scale Economies and Technical Progress in the Canadian Life Insurance Industry", International Journal of Industrial Organization (Netherlands) No. 3, September 1985, pp. 345-361.

DENNY, M., "Measuring the Real Output of the Insurance Industry: A Comment", Review of Economics and Statistics No. 62, February 1980, pp. 150-152.

DENNY, M. and PINTO, C., "An Aggregate Model and Multi-Product Technologies, Production Economies: A Dual Approach to Theory and Applications 2, ed. Melvyn Fuiss and Daniel McFadden, North-Holland, Amsterdam, 1978.

DOHERTY, Neil, "The Measurement of Output and Economies of Scale in Property-Liability Insurance, Journal of Risk and Insurance No. 49, September 1982, pp. 390-402.

DUBOIS, P., Estimation d'une fonction de coit hedonique: compagnies d'assurance IARD, Cinquièmes journées de Micro-Economie Appliquée, Toulouse, 9-10 juin 1988.

EISEN, R., "Economies of Scale in Italian Non-Life Insurance, Market Size and Concentration: Insurance and the European Internal Market (1992)", The Geneva Papers on Risk and Insurance: Issues and Practices No. 60, July 1991, pp. 263-281.

ETGAR, Michael, "Cost Effectiveness in Insurance Distribution", Journal of Risk and Insurance No. 44, June 1977, pp. 211-22.

FECHER, F., PERELMAN, S. and PESTICAU, P., "Scale Economies and Performance in the french Insurance Industry", The Geneva Papers on Risk and Insurance: Issues and Practices No. 60, July 1991 , pp. $315-326$.

FINSINGER, Jörg and SCHMIDT, F.A., "Prices, Distribution Systems, and Regulatory Intervention in European Insurance Markets", Geneva Papers on Risk and Insurance: Issues and practices No. 19, January 1994, pp. 22-36.

FIELDS, Joseph A., and MURPHY, Neil B., "An Analysis of Efficiency in the Delivery of Financial Services: The Case of Life Insurance Agencies", Journal of Financial Services Research No. 2, October 1989, pp. 343-356. 
GARDNER, L.A. and GRACE, M.F., "X-efficiency in the U.S. Life Insurance Industry", Journal of Banking and Finance No. 17, September 1993, pp. 497-510.

GEEHAN, R., "Return to Scale in the Life Insurance Industry", Bell Journal of Economics No. 8, Autumn 1977, pp. 497-513.

GOLDBERG, L. G., HANWECK, G.A., KEENAN, M., and YOUNG, A. , "Economies of Scale and Scope in the Securities Industry", Journal of Financial Services Research No. 4, February 1991, pp. $91-107$.

GRACE, M.F. and TIMME, S.G., "An Examination of Cost Economies in the U.S. Life Insurance Industry”, Journal of Risk and Insurance No. 59, March 1992, pp. 72-103.

GROSSMAN, SANFORD and HART, Oliver, "The Costs and Benefits of Ownership: A Theory of Vertical and Lateral Integration”, Journal of Political Economy, August 1986, pp. 691-719.

HARRINGTON, S. E., “Operating Expenses for Agency and Nonagency Life Insurers: Further Evidence", Journal of Risk and Insurance No. 49, June 1982, pp. 229-253.

JOHNSON, J. E., FLANIGAN, G.B. and Y.WEISBART, S.N., "Return to Scale in the Property-Liability Insurance Industry”, Journal of Risk and Insurance No. 48, September 1981, pp. 375-427.

JOSKOW, P., "Cartels, Competition and Regulation", Bell Journal of Economics and Management Science No. 4, Autumn 1973, pp. 375-427.

KAYE, G., "Economies of Scale in the U.K. Life Insurance Industry: An Empirical Approach", The Geneva Papers on Risk and Insurance: Issues and Practices No. 60, July 1991, pp. 302-314.

KIM, Won Joong, MAYERS, David and SMITH, Clifford Jr., On the Choice of Insurance Distribution Systems, Working Paper, Ohio State University, 1991.

KLEIN, Benjamin, CRAWFORD, Robert and ALCHIAN, Armen, "Vertical Integration, Appropriable Rents, and the Competitive Contracting Process", Journal of Law and Economics No. 21, October 1978, pp. 297-326.

LABOUL, A. and LAUWERS, M., Une approche de type - Economie Industrielle - appliquée à l'étude de l'industrie de l'assurance en Belgique. Article presented at Société Suisse de Statistique et d'Economie Politique, 1986.

MARVEL, Howard, "Exclusive Dealing”, Journal of Law and Economics No. 25, April 1982, pp. $1-25$.

MAYERS, David and SMITH Clifford Jr., "Contractual Provisions, Organizational Structure, and Conflict Control in Insurance Markets”, Journal of Business No. 54, July 1981, pp. 407-34.

OUTREVILLE, J. F., “L'assurance en France: essais d'analyses macroéconomiques", Etudes et Dossiers. Association Internationale pour l'Etude de l'Economie de l'Assurance (Association de Genève), 1987.

PORTER, Michael, Competitive Advantage: Creating and Sustaining Superior Performance, Free Press, NY, 1985.

PRAETZ, P., "A Note on Economies of Scale in the United Kingdom Property-Liability Insurance Industry", Journal of Risk and Insurance No. 52, June 1985, pp. 315-320.

REAGAN, Laureen and TENNISON Sharon, Agent Discretion and the Choice of Insurance Marketing System, Working Paper, University of Pennsylvania, 1993.

ROSA, J. J., "Les économies de dimension des institutions financières", Revue de la Banque, 1974, pp. $491-497$.

SASS, Tim and GISSER, Micha, "Agency Costs, Firm Size, and Exclusive Dealing", Journal of Law and Economics No. 32, October 1989, pp. $381-400$.

SCHLESINGER, H. and VENEZIAN, E., "Ex-Ante Loss Control by Insurers: Public Interest for Higher Profit", Journal of Financial Services Research No. 4, June 1990, pp. 83-92.

SHEPARD, R., The Theory of Cost and Production Functions. Princeton University Press, 1970. 
SKOGH, G. , "Returns to Scale in the Swedish Property-Liability Insurance Industry", Journal of Risk and Insurance No. 50, June 1982, pp. 218-255.

SPITZER, J., "Variance Estimates in Models with The Box-Cox Transformation, Implications for Estimation and Hypothesis Testing", Review of Economics and Statistics No. 66, November 1984, pp. 645-652.

SURET, J. M., "Economies d'échelle et complémentarité de coût dans le secteur des assurances", The Geneva Papers on Risk and Insurance: Issues and Practices No. 59, April 1991, pp. 236-256.

WITT, Robert C. and AIRD, Paul, "Contestable Markets for Property-Liability Insurance: Is Rate and Form Regulation Necessary?", CPCU Journal No. 45, March 1992, pp. 30-48.

ZWEIFEL, P. and GHERMI, P., "Exclusive vs. Independent Agencies: A Comparison of Performance", The Geneva Papers on Risk and Insurance Theory No. 15, September 1990, pp. 171-192. 